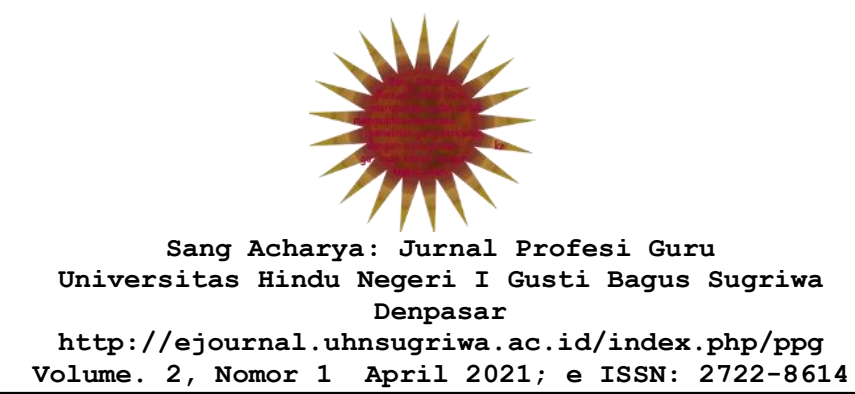

\title{
SEKOLAH SEBAGAI IDENTITAS STRATEGIS DALAM MENGIMPLEMENTASIKAN PENDIDIKAN KARAKTER ANAK
}

\author{
Ni Kadek Wita Pradnyayoni \\ Universitas Hindu Negeri I Gusti Bagus Sugriwa Denpasar \\ witapradnyayono@gmail.com
}

Diterima 26 April 2021, direvisi 30 April 2021, diterbitkan 1 Mei 2021

\begin{abstract}
Abstrak
Mendidik seseorang hanya dalam aspek kecerdasan otak saja dan tanpa aspek moral adalah ancaman marabahaya kepada masyarakat. Realita yang terjadi, sekolah sebagai lembaga pendidikan cenderung mendidik peserta didik cerdas secara kognitif dan mengabaikan aspek moral, sehingga dekadensi moral dialami oleh bangsa Indonesia. Upaya untuk mengatasi problem tersebut, muncullah gagasan untuk melaksanakan pendidikan karakter dalam skala makro dan mikro melalui kegiatan pendidikan sekolah, keluarga dan masyarakat. Sekolah bertanggungjawab dalam menanamkan pendidikan karakter, menanamkan ilmu pengetahuan dan nilai agama, sehingga terjadi keseimbangan antara kecerdasan otak dan aspek moral anak didik. Ilmu pengetahuan dan nilai moral sebagai kunci kebajikan. Ilmu pengetahuan dan aspek moral yang ditanamkan melalui sekolah, sehingga peluang dan tantangan yang dihadapi di era globalisasi dan perkembangan teknologi informasi dan komunikasi dapat dimanfaatkan dengan baik dan benar, sehingga tujuan Pendidikan Nasional dapat terwujud.

Kata Kunci: Sekolah, Identitas Strategis Pendidikan Karakter, Kepribadian Anak

\section{Abstract}

Educate someone only in the aspect of intelligence alone and without the moral aspect is a threat to the public distress. The realitythat happens, the school as an educational institution to educate learnes tend to be intelligent cognitively and ignore the moral aspect, so that the moral decadence experienced by Indonesia. efforts to address the problem, came the idea to implement charakter education in the macro and micro scale through school education, the family, and sociaty. Schools are responsible for instilling character education, science and instill religious values, resulting in a balance, between intelegence and moral aspects of learners. Science and moral aspect are implanted through the school can be used as a tool to address the opportnities and challenges in the era of globalization and development of information and communication technologies can be used properly, so that the national education goals can be realized.
\end{abstract}

Keywords: schools, strategic entities, character education, the child's personality

\section{A. Pendahuluan}

Mendidik seseorang dalam aspek kecerdasan otak dan bukan aspek moral adalah ancaman marabahaya kepada masyarakat. Sampai saat ini statemen tersebut menjadi 


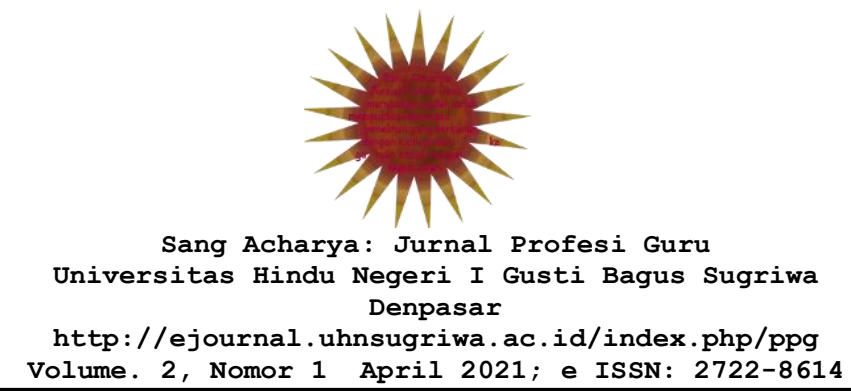

perdebatan yang tidak bertepi. Ada yang menginginkan pendidikan terfokus pada kecerdasan otak dan ada yang menganjurkan, jika pendidikan lebih mengedepankan aspek moral. Di samping itu, ada yang menginginkan agar ada integrasi antara kecerdasan otak dengan aspek moral dengan proporsi yang berlainan, ada yang mengintegrasikan keduanya dan cenderung ke kecerdasan otak dan ada mengintegrasikan keduanya tapi cenderung ke aspek moral.

Realita yang terjadi, sekolah sebagai lembaga pendidikan cenderung mendidik peserta didik cerdas secara kognitif dan mengabaikan aspek moral. Dekadensi moral dialami oleh bangsa Indonesia. Tentu tidak adil, jika menyalahkan sekolah sebagai biang keladi dari problem ini, karena sekolah merupakan subsistem dari sebuah sistem pendidikan nasional. Walaupun kurikulum sudah berkali-kali mengalami pergantian mulai dari kurikulum dengan penekanan pada isi sampai terakhir kurikulum tahun 2013 menekankan aspek sikap sosial dan aspek religius.

Guna mengatasi problem tersebut, muncullah gagasan untuk melaksanakan pendidikan karakter dalam skala makro dan mikro. Dalam skala makro, yaitu dalam kehidupan berbangsa dan bernegara. Pelaksanaan pendidikan karakter merupakan komitmen seluruh sektor kehidupan, bukan hanya sektor pendidikan nasional. Keterlibatan aktif dari sektor-sektor pemerintah lainnya, khususnya sektor keagamaan, kesejahteraan, pemerintahan, komunikasi, dan hak asasi manusia, serta pemuda dan olah raga juga sangat dimungkinkan. Pada skala mikro, pendidikan karakter berpusat pada sekolah. Sekolah merupakan wilayah utama yang secara optimal memanfaatkan dan memberdayakan semua lingkungan belajar yang ada untuk menginisiasi, memperbaiki, menguatkan, dan menyempurnakan secara terus menerus proses pendidikan karakter. Secara mikro, pengembangan karakter dibagi dalam empat pilar, yakni kegiatan belajarmengajar di kelas, kegiatan keseharian dalam bentuk pengembangan budaya satuan pendidikan formal dan nonformal, kegiatan kokurikuler dan ekstrakurikuler, serta kegiatan keseharian di rumah dan masyarakat.

\section{B. Pembahasan}

\section{Tanggung Jawab dan Kewajiban Sekolah Dalam Implementasi Pendidikan Karakter}

Pendidikan yang terutama dianggap sebagai proses pengoperasian kebudayaan, pengembangan ilmu pengetahuan berarti membina pribadi manusia untuk mengerti, berpengetahuan dalam arti seluas-luasnya. Berpengetahuan atau tahu adalah asas utama untuk kebaikan menuju kesempurnaan. Pandangan demikian ditanamkan oleh Socrates bahwa pengetahuan adalah kebajikan. Socrates mensinthesakan ilmu dan nilai dalam prinsip bahwa ilmu (tahu) adalah kunci kabajikan, sedangkan ilmu hanya mungkin dimiliki melalui pendidikan, baik belajar melalui pendidikan formal maupun informal. Sedemikian jauh, ilmu pengetahuan mempunyai nilai-bina atas kepribadian. Dengan ilmu, sikap kritis-rasional, broadmindedness (lapang dada), obyektif, akan berkembang. Di samping itu, ilmu pengetahuan selalu mengandung nilai-nilai praktis di dalam kehidupan, baik sebagai pribadi maupun sebagai warga masyarakat.

Dalam masyarakat bangsa-bangsa modern, lebih-lebih dalam rangka menjelang masa depan yang super modern, pendidikan dianggap satu-satunya media untuk membina 


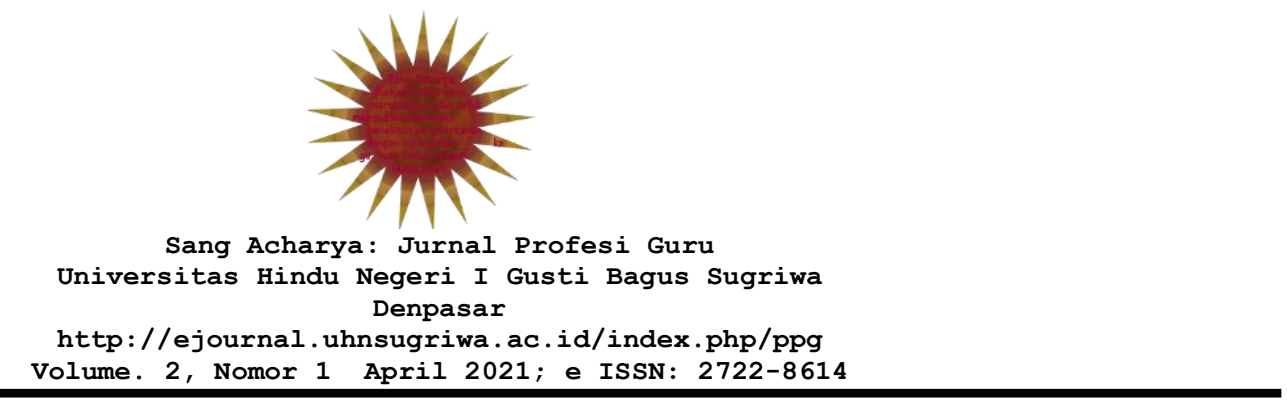

keseimbangan antara bangsa yang maju di satu pihak dan bangsa yang ketinggalan di lain pihak. Dengan perkataan lain, bangsa yang underdeveloped atau developing countries berusaha mengejar ketinggalan mereka melalui pendidikan. Terutama belajar dari bangsa yang maju itu tentang apa yang mereka capai sekarang.

Pendidikan dalam wujudnya, selalu bertujuan membina kepribadian manusia, baik demi ultimate-goal maupun bagi tujuan-tujuan dekat. Tujuan akhir pendidikan adalah kesempurnaan pribadi. Prinsip ini terutama berpangkal pada asas self-realisasi, yakni merealisasi potensi-potensi yang sudah ada di dalam martabat kemanusiaannya. Potensi-potensi itu, baik berupa potensi-potensi intelektual, mental, rasa, karsa, maupun kesadaran moral, bahkan juga aspek-aspek keterampilan phisik dan perkembangan jasmaniah. Essensia kepribadian manusia yang tersimpul dalam aspek-aspek: individualitas, sosialitas, dan moralitas hanya mungkin menjadi realita (tingkah laku, sikap) melalui pendidikan yang diarahkan kepada masing-masing essensia itu. Harga diri, kepercayaan pada diri sendiri, rasa tanggung jawab, dan sebagainya juga akan tumbuh dalam kepribadian manusia melalui proses pendidikan. Dunia dan kebudayaan modern tidak sedikitpun meragukan nilai pendidikan bagi kehidupan umat manusia. Kepemimpinan suatu bangsa dan proses regenerasi mereka tidak mungkin tanpa pendidikan. Bahkan secara individual, tiada pekerjaan di dalam kehidupan manusia yang akan efektif dilaksanakan seseorang termasuk bahasa/bicara, berjalan, tanpa melalui proses pendidikan. Hal tersebut akan lebih-lebih berlaku bagi suatu pekerjaan sosial, profesi, dalam semua bidang dan semua tingkatan. Dalam membina kepribadian, pendidikan mematangkan kepribadian yang tersimpul dalam derajat integritas dan kebijaksanaan sebagai tingkat ideal. Ilmu pengetahuan mempercepat proses itu.

Menurut Wiyani (2012:31) sekolah menjadi lembaga pendidikan sebagai media berbenah diri dan membentuk nalar berpikir yang kuat dengan ilmu pengetahuan dan teknologi serta membentuk karakter peserta didik dengan nilai-nilai luhur. Sekolah merupakan wahana yang mencerdaskan dan memberikan perubahan kehidupan anak didik. Dengan kata lain, sekolah mampu memberikan warna baru bagi kehidupan anak ke depannya, sebab di sekolah mereka ditempa untuk belajar berbicara, berpikir, dan bertindak. Artinya, bahwa melalui sekolah anak dididik untuk menjadi dirinya sendiri. Tingkat keberhasilan suatu bangsa dalam konteks kehidupan manusia yang sangat luas diukur dari bagaimana sekolah berperan dalam membangun kemandirian dan kecerdasan anak didik.

Wiyani (2011:56) menjelaskan bahwa sekolah bertanggung jawab menanamkan pengetahuan-pengetahuan baru yang reformatif dan tranformatif dalam membangun bangsa yang maju dan berkualitas. Sekolah juga bertangung jawab mentransformasikan nilai-nilai luhur kepada anak didik. Dengan demikian, peran sekolah sangat besar dalam menentukan arah dan orientasi bangsa ke depan. Dengan sekolah, pemerintah mendidik bangsanya untuk menjadi seorang ahli yang sesuai dengan bidang dan bakatnya si anak didik, yang berguna bagi dirinya sendiri, dan berguna bagi nusa, dan bangsa. Dengan sekolah pula, umat manusia yang berperadaban dan beragama, mendidik anak-anaknya untuk menjadi anak yang memiliki kecerdasan intelektual, emosional, dan spiritual yang tinggi sebagai bekal untuk melanjutkan dan memperjuangkan agamanya.

\section{Sekolah di Era Teknologi Informasi dan Komunikasi}




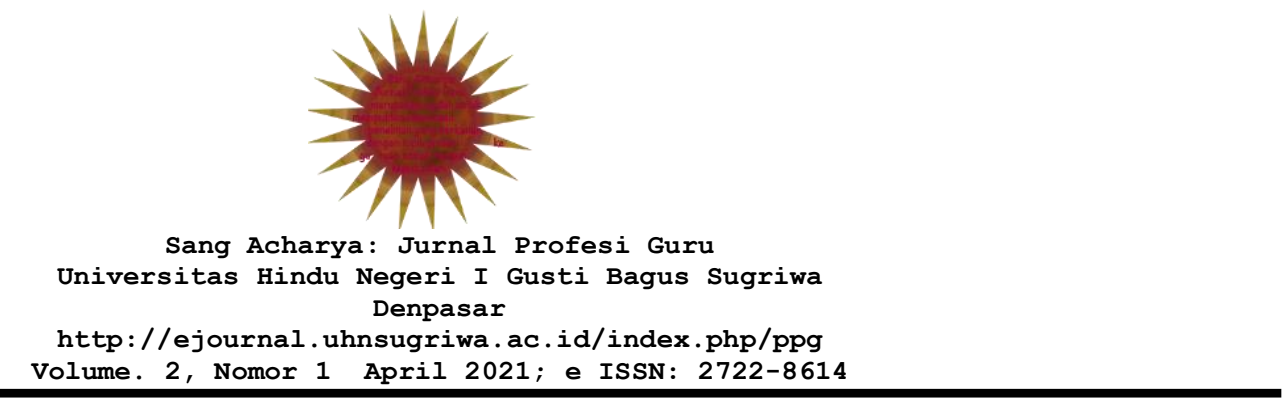

Kencangnya arus globalisasi semakin terasa menghantam berbagai aspek kehidupan masyarakat. Menurut Tofler (dalam Wiyani (2012:32) saat ini sedang terjadi pergeseran kekuasaan (powershift) yang menggerogoti setiap pilar sistem kekuasaan lama yang secara mendasar telah dan akan mengubah kehidupan keluarga, bisnis, politik, negara-negara, dan struktur kekuasaan global itu sendiri. Kekuatan, kekayaan, dan pengetahuan menjadi tiga dasar kekuasaan yang menentukan kompetisi global.

Dalam era informasi, eksistensi keluarga sebagai bagian dari masyarakat juga memberikan implikasi penting bagi sistem baru pendidikan. Menurut Reigeluth dan Garfinkel (dalam Wiyani, 2012:32), model karakteristik masyarakat, informasi tersebut antara lain:

a. Tujuan dan model berkisar pada proses pengorganisasian iptek mengenai informasi dan pengembangan pengetahuan.

b. Dasar kekuatannya adalah perluasan kekuatan kognitif dengan teknologi tinggi.

c. Paradigmanya adalah berpikir sistemik, munculnya hubungan sebab akibat (causality), kompleksitas yang dinamis, orientasi ekologi.

d. Berkembangnya teknologi; proses pengumpulan, pengorganisasian, penyimpanan informasi, jaringan komunikasi, sistem perencanaan dan rancangan.

e. Komoditi pokok; informasi dan pengetahuan sebagai kunci produk, manusia profesional, dan pelayanan teknik adalah komuditi utamanya.

f. Pola konsumsi lebih kecil dan lebih efisien.

g. Karakteristik organisasi; terpadu, sinergi, perubahan, dan fleksibilitas.

Di era teknologi, sekolah menghadapi tantangan dan sekaligus memiliki peluang. Dunia yang semakin mengglobal sekarang ini, bergerak dan berubah semakin cepat dan kompetitif. Semua bidang mengalami pergeseran dan tantangan, termasuk sekolah sebagai lembaga pendidikan. Sekolah menghadapi tantangan serius untuk mampu mengikuti sekaligus berada di garda depan perubahan global tersebut. Proses pendidikan di sekolah pada era informasi dan komunikasi ini, harus berbasis pada ilmu pengetahuan dan teknologi. Pemanfaatan berbagai teknologi informasi dan komunikasi menjadi hal yang fundamental bagi kemajuan dunia pendidikan di sekolah dewasa ini. Kemajuan teknologi informasi dan komunikasi telah memungkinkan diskusi jarak jauh dengan salah satu pendidik atau pakar pada suatu wilayah atau negara dengan pihak-pihak yang membutuhkan di wilayah yang lain.

Pemanfaatan komputer, internet, atau multimedia untuk pendidikan harus sudah di mulai sejak sekolah dasar. Sudah saatnya, sejak dini diperkenlkan dunia teknologi informasi dan komunikasi dalam pendidikan untuk memasuki dunia global. Dengan kemajuan teknologi informasi dan komunikasi, akan memudahkan peserta didik untuk mengakses informasi yang dibutuhkan dalam proses pendidikan. Namun di balik peluang tersebut, beberapa tantangan yang dihadapi sekolah, antara lain:

a. Proses pendidikan cenderung cognitif oriented. Hal tersebut merupakan salah satu dari karakteristik masyarakat di era informasi.

b. Munculnya persaingan antarsekolah dalam ranah material. Sekolah membutuhkan berbagai fasilitas untuk mendukung pemanfaatan teknologi 


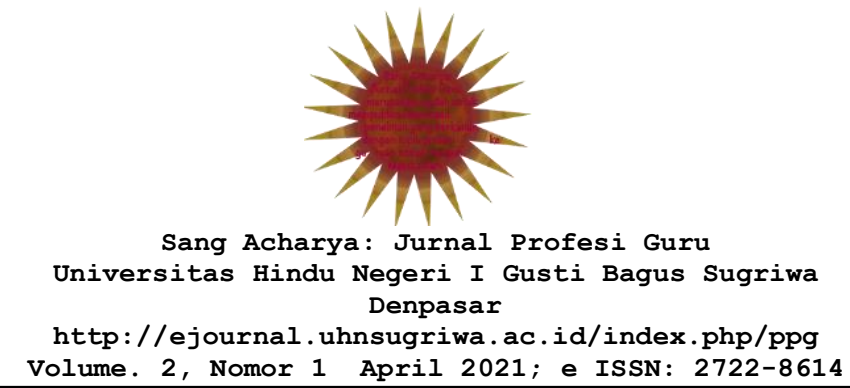

informasi dan komunikasi, tiap sekolahpun berusaha memenuhinya bahkan terjadi persaingan antarsekolah, sehingga sekolah cenderung mengabaikan pembangunan karakter peserta didiknya.

c. Mengikisnya nilai-nilai agama pada peserta didik. Tranformasi pendidikan yang terjadi melalui pemanfaatan teknologi informasi dan komunikasi cenderung cognitif oriented, sehingga tranformasi nilai pun terabaikan. Salah satu contoh konkretnya pada kasus penggunaan fasilitas facebook (media jejaring sosial) dapat dimanfaatkan sebagai media tranformasi pengetahuan dan sosial. Namun, dalam penggunaannya, banyak pemakai yang mengabaikan pekerjaan, belajar, dan kewajiban lain dan lebih mementingkan diri untuk ber-facebook ria.

Menurut Wiyani (2011:61) bahwa bagaimanapun majunya teknologi informasi dan komunikasi, teknologi tersebut tidak dapat menggantikan peran guru dalam pendidikan. Secanggih apapun teknologi yang digunakan untuk mendapatkan ilmu pengetahuan, peserta didik masih tetap membutuhkan sosok guru sebagai pemandunya. Peran strategis guru guru tersebut harus bisa dimanfaatkan dengan optimal untuk meminimalisasi efek negatif yang berasal dari tantangan-tantangan. Sebagai seorang fasilitator dalam transformasi pengetahuan, guru hendaknya mampu mentransformasikan nilai-nilai kebajikan pada peserta didik, agar moral mereka tidak terkikis oleh kemajuan teknologi informasi dan komunikasi. Pandangan Socrates bahwa pengetahuan adalah kebajikan. Ilmu dan nilai adalah kunci kebajikan, sedangkan ilmu hanya mungkin dimiliki melalui pendidikan, baik melalui pendidikan formal maupun informal. Manusia adalah subyek, sekaligus sebagai obyek pendidikan. Manusia dewasa yang berkebudayaan adalah subyek pendidikan dalam arti yang bertanggung jawab menyelenggarakan pendidikan. Manusia mengemban amanat untuk membina masyarakat, memelihara alam lingkungan hidup bersama, terutama bertanggung jawab atas martabat kemanusiaannya (human dignity).

Menurut Langeveld bahwa hakikat kemanusiaan ditinjau dari segi pendidikan, adalah Animal educabile, yaitu makhluk yang dapat dididik; Animal educandum, yaitu makhluk yang harus dididik; Homo education, yaitu makhluk yang di samping dapat dan harus dididik juga dapat dan harus mendidik. Ilmu pengetahuan dan filsafat tentang hakikat manusia, dijadikan dasar untuk pembinaan kepribadian manusia, sehinggga struktur jiwa dan hakikat manusia, pembinaan aspek kepribadian menjadi lebih terarah pada sasaran yang tepat, serta pendidikan sebagai prasarana usaha pembinaan kepribadian. Peranan pendidikan dalam pembinaan kepribadian tersimpul dalam usahanya merealisasikan tujuan pendidikan yang bersumber atau ditentukan oleh asasasas pandangan ontologis dan axiologis.

\section{Sekolah Sebagai Wahana Pendidikan Karakter}

Mengacu pada pandangan Socrates bahwa ilmu dan nilai adalah kunci kebajikan, sedangkan ilmu hanya mungkin dimiliki melalui pendidikan, baik melalui pendidikan formal maupun informal. Artinya bahwa di sekolah anak mengalami perubahan dalam tingkah lakunya. Proses perubahan tingkah laku dalam diri anak sesuai dengan nilai-nilai sosial dan kebudayaan yang tertuang dalam kurikulum. Kurikulum pendidikan yang dilaksanakan oleh guru, salah satunya berfungsi untuk membentuk tingkah laku menuju 


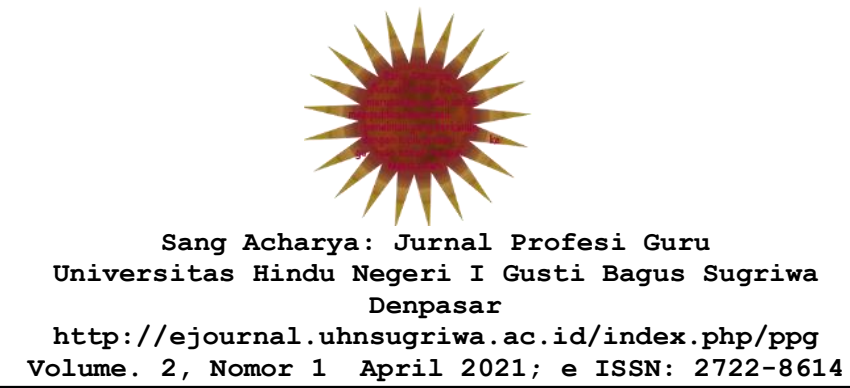

kepribadian yang dewasa secara optimal. Di sekolah, berlangsung proses tranformasi nilai-nilai luhur melalui pendidikan karakter. Pendidikan karakter merupakan kata kunci dari proses transformasi nilai-nilai luhur di sekolah. Guru menjadi transformer nilai-nilai luhur kepada peserta didik untuk menjadi bagian dari masyarakat yang berbudaya.

Menurut Wiyani (2011:60) fungsi transformasi nilai-nilai luhur yang dilaksanakan oleh sekolah mencakup lima dimensi, yaitu:

1. Pendidikan tidak hanya mencakup pengetahuan dan keterampilan semata, tetapi juga sikap, nilai, dan kepekaan pribadi.

2. Peran seleksi sosial (tidak hanya mencakup pemberian sertifikat, tetapi juga melakukan seleksi terhadap peluang kerja).

3. Fungsi indoktrinasi.

4. Fungsi pemeliharaan anak.

5. Aktivitas kemasyarakatan.

Jadi, sekolah memiliki fungsi pendidikan, peran sosial, indoktrinasi, pemeliharaan, dan aktivitas kemasyarakatan. Sekolah sebagai wahana tranformasi nilainilai luhur dan pengetahuan anak akan menentukan corak berpikir dan berprilaku yang sesuai dengan norma-norma yang diyakini dan dimiliki masyarakat. Pada gilirannya, kepribadian anak akan terbentuk sesuai dengan akar budayanya dengan kemampuan merespon perubahan di masyarakat.

\section{Kesimpulan}

Sekolah sebagai lembaga pendidikan bertanggung jawab dan berkewajiban dalam mengimplementasikan pendidikan karakter, dengan alasan bahwa pendidikan yang terutama dianggap sebagai proses pengoperasian kebudayaan, pengembangan ilmu pengetahuan berarti membina pribadi manusia untuk mengerti, berpengetahuan dalam arti seluas-luasnya. Ilmu pengetahuan dan nilai adalah kunci kabajikan, sedangkan ilmu hanya mungkin dimiliki melalui pendidikan, baik belajar melalui pendidikan formal maupun informal. Ilmu pengetahuan selalu mengandung nilai-nilai praktis di dalam kehidupan, baik sebagai pribadi maupun sebagai warga masyarakat. Essensia kepribadian manusia yang tersimpul dalam aspek-aspek: individualitas, sosialitas, dan moralitas hanya mungkin menjadi realita (tingkah laku, sikap) melalui pendidikan yang diarahkan kepada masing-masing essensia itu. Harga diri, kepercayaan pada diri sendiri, rasa tanggung jawab, dan sebagainya juga akan tumbuh dalam kepribadian manusia melalui proses pendidikan.

Sekolah menjadi lembaga pendidikan sebagai media berbenah diri dan membentuk nalar berpikir yang kuat dengan ilmu pengetahuan dan teknologi serta membentuk karakter peserta didik dengan nilai-nilai luhur. Sekolah merupakan wahana yang mencerdaskan dan memberikan perubahan kehidupan anak didik. Dengan kata lain, sekolah mampu memberikan warna baru bagi kehidupan anak ke depannya, sebab di sekolah mereka ditempa untuk belajar berbicara, berpikir, dan bertindak. Artinya, bahwa melalui sekolah anak dididik untuk menjadi dirinya sendiri.

Kencangnya arus globalisasi dan era informasi, sekolah bertanggung jawab menanamkan pengetahuan baru yang reformatif dan tranformatif dalam membangun bangsa yang maju dan berkualitas; mentransformasikan nilai luhur kepada anak didik. Di era teknologi, sekolah menghadapi tantangan dan sekaligus memiliki peluang, semakin 


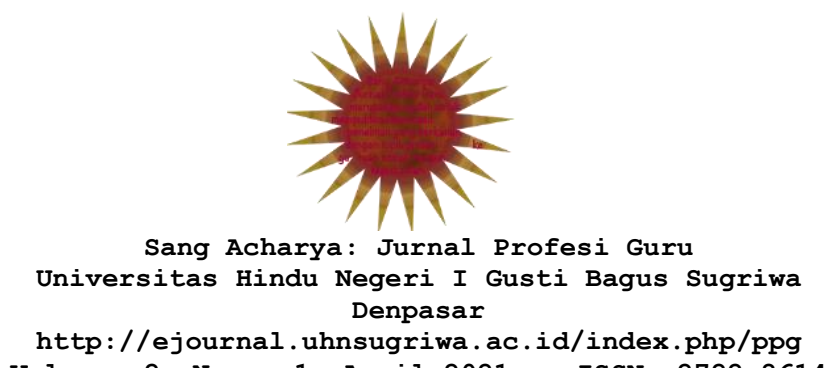

Volume. 2, Nomor 1 April 2021; e ISSN: 2722-8614

mengglobal, bergerak, berubah semakin cepat dan kompetitif. Dengan kemajuan teknologi informasi dan komunikasi, akan memudahkan peserta didik untuk mengakses informasi yang dibutuhkan dalam proses pendidikan. Namun di balik peluang tersebut, beberapa tantangan yang dihadapi sekolah, antara lain 1) proses pendidikan cenderung cognitif oriented; 2) munculnya persaingan antarsekolah dalam ranah material, 3) mengikisnya nilai agama pada peserta didik.

Bagaimanapun majunya teknologi informasi dan komunikasi, tidak dapat menggantikan peran guru dalam pendidikan. Guru menjadi transformer nilai-nilai luhur kepada peserta didik untuk menjadi bagian dari masyarakat yang berbudaya. Jadi, sekolah memiliki fungsi pendidikan, peran sosial, indoktrinasi, pemeliharaan, dan aktivitas kemasyarakatan.

\section{Daftar Bacaan}

Mulyana, 2002. Kurikulum Berbasis Kompetensi. Konsep, Karakteristik, dan Implementasi. Bandung. PT. Remaja Rosdakarya.

Tim Pengembang MKDP Kurikulum dan Pembelajaran. 2013. Kurikulum dan Pembelajaran. Rajawali Pers. PT Rajagrafindo Persada

Wiyani, Novan Ardy, 2011. Pengantar Ilmu Pendidikan Islami. Rancang Bangun Konsep Pendidikan Monokhomik-Holistik. Penerbit: Bumiayu, STKIP Islam Bumiayu

Wiyani, Novan Ardy, 2012. Manajemen Pendidikan Karakter. Konsep dan Implementasinya di Sekolah. Penerbit: Pedagogia, PT Pustaka Insan Madani, Anggota IKAPI) Yogyakarta. 